\title{
THE ROLE OF INSTRUMENTS IN THE DISSEMINATION OF THE CHEMICAL REVOLUTION
}

\author{
TREVOR H. LEVERE \\ Institute for the History and Philosophy of Science and Technology, \\ University of Toronto, Canada
}

\begin{abstract}
The spread of the late eighteenth-century chemical revolution depended on access to appropriate apparatus. Theories depend upon practice, which depends upon instruments. Pneumatic chemistry required new apparatus for the isolation, measurement, and admixture of different gases. Lavoisier's pneumatic chemistry involved his new, refined, expensive gasometers. The development of cheaper but still functional gasometers by chemists and instrument makers enabled chemists outside Paris to repeat and extend Lavoisier's key experiments. Lavoisier's superb precision balances were an important part of his arsenal. Glass apparatus made increasing demands on glass blowers. The bottle factories that had supplied Black in Edinburgh and later Proust in Segovia were no longer adequate.
\end{abstract}

Dr. Joseph Black, in his lectures at the University of Edinburgh, was always wary of theory. In 1775, he expressed his habitual note of caution. "While our knowledge [of the science of chemistry] is imperfect, it is apt to run into errour: but Experiment is the thread that will lead us out of the labyrinth." ${ }^{1} \mathrm{He}$ was sceptical of theoretical innovations in general, and was true to himself in resisting the new French theory until 1786, when he visited Paris. There he saw demonstrations of some of the key experiments adduced in favour of Lavoisier's ideas, including that of the composition of water.

1 Alexander LAW, "Notes of Dr. Black's Lectures on Chemistry" (MS University of Edinburgh Library, June-December 1775), I, 5; quoted in Henry GUERLAC, BLACK, JOSEPH , Dictionary of Scientific Biography, ed. C. C. GILLISPIE, vol. 2, p. 181. 
After returning to Edinburgh, he recommended the new theory to his colleagues and students, but he never accepted the new language of chemistry proposed by Guyton de Morveau, Lavoisier, and others ${ }^{2}$. Nor did he accept the necessity of the new apparatus that Lavoisier insisted was essential for the demonstration of his new chemistry. Black's apparatus that remains in Edinburgh is resolutely simple, and crudely made. His retorts and other vessels were made in local bottle factories, from green glass inexpertly blown and bent, as we can see in figure $1^{3}$. Black's instruments have none of the polish of Lavoisier's. His balance could weight to one part in 200 , compared with the astonishing one part in 400,000 of Lavoisier's great balance; he had no true gasometer; and the pieces of his glassware were luted together, in ways that were likely to contaminate the contents, suffer leakage, and were moreover often impossible to disassemble. Lavoisier's pieces of glassware, in contrast, were coupled by brass screw threads lacquered to the glassware, and capable of modular assembly and disassembly. ${ }^{4}$ Lavoisier asserted, in his Traité élémentaire de chimie of 1789 , that the instruments he described in part III of that work were absolutely essential to the new chemistry. ${ }^{5}$ In the sense that instruments designed to determine results within a given theoretical context ${ }^{6}$ give implicit validation to that context, Lavoisier was right. Perhaps this is why Black never sought to replicate Lavoisier's apparatus in performing his own lecturedemonstrations in Edinburgh.

${ }^{2}$ Guyton de Morveau, Antoine Laurent Lavoisier, Claude Louis Berthollet, and Antoine François FOURCROY, Méthode de nomenclature chimique (Paris, Cuchet ,1787).

${ }^{3}$ Retort, National Museums of Scotland, registered no. NMST1858.275.40. See also R. G. W. ANDERSON, The Playfair Collection and the Teaching of Chemistry at the University of Edinburgh 1713-1858 (Edinburgh, The Royal Scottish Museum, 1978), and "A Source for $18^{\text {th }}$-Century Chemical Glassm, Proceedings of the Eleventh International Scientific Instrument Symposium, Bologna University, Italy, 9-14 September 1991, edited by GIORGIO DraGoNi, Anita MCCONNELL, and Gerard L'E. TURNER (Bologna, Grafis Edizioni, 1994), pp.47-52.

${ }^{4}$ In the nineteenth century, the development of extruded glass tubing and rubber tubing made modular assembly and disassembly both easier and cheaper. So too did the mass production of ground glass stoppers, replacing the individually ground stoppers of the late eighteenth century. See William A. Smeaton, «Platinum and Ground Glass: Some Innovations in Chemical Apparatus by Guyton de Morveau and Others", Instruments and Experimentation in the History of Chemistry, edited by Frederic L. HOLMES and Trevor H. LEVERE (Cambridge, Mass., MIT Press, 2000), pp. 211-238.

${ }^{5}$ A. L. LAVOISIER, Traité elémentaire de chimie, 2 vols. (Paris, Cuchet, 1789), vol. 2 pp.326, 347.

${ }^{6}$ Holmes and LeVERE, eds. (2000), p. xiii. 


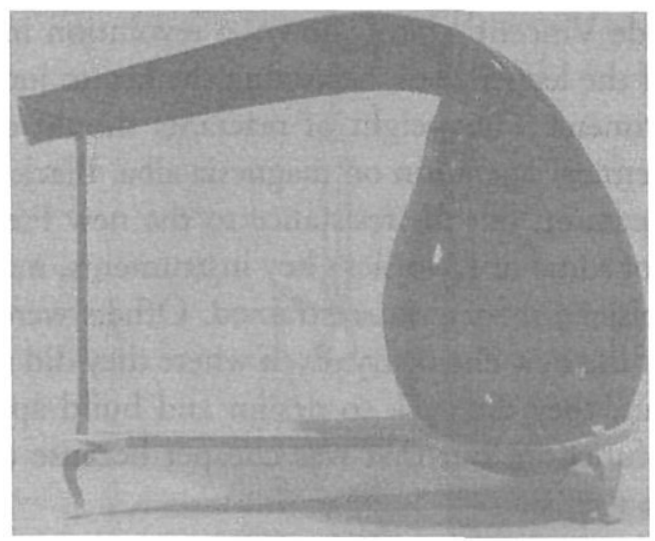

Figure 1: One of Joseph Black's retorts in green glass, registered no. NMST1858.275 40, by permission of the Trustees of the National Museums of Scotland.

And yet Black was one whose merit Lavoisier acknowledged. ${ }^{7}$ Black's work, in his very first publication ${ }^{8}$, involved precise quantitative work, and was informed by the principle of the conservation of weight; Black was therefore able to infer that the weight of fixed air released when magnesia alba was calcined was equal to the loss in weight of the solid residue. He also characterized the air chemically. Black's quantitative gas chemistry founded upon conservation of weight was an instance of quantitative method that Lavoisier built on and extended, and his study of fixed air would be incorporated into Lavoisier's account of combustion. Lavoisier's former colleague Fourcroy, years after Lavoisier's execution, said that the chemical revolution had been a revolution in pneumatic chemistry, the chemistry of gases. It was also, as Frederic Lawrence Holmes, ${ }^{9}$ and Jean-Pierre Poirier, ${ }^{10}$ and

${ }^{7}$ A. L. Lavoisier, Opuscules physiques et chimiques (Paris, Durand, 1774; $2^{\text {nd }}$ edition Paris, Deterville, 1801), pp. 37-43, reprinted in Oeuvres de Lavoisier, 6 vols. (Paris, 1862-93), vol. 1 (1864), pp.468-471.

8 Joseph BLACK, "Experiments upon Magnesia Alba, Quick-Lime, and other Alcaline Substances", Essays and Observations, Physical and Literary. Read before the Philosophical Society in Edinburgh, and published by them, 2 (1756), 172-248. This is an expanded version of his 1755 MD dissertation, and was reprinted as Alembic Club Reprint no. 1 (1893).

${ }^{9}$ Frederic Lawrence Holmes, Antoine Lavoisier - The Next Crucial Year: Or The Sources of his Quantitative Method in Chemistry (Princeton, NJ, Princeton University Press, 1998).

${ }^{10}$ Jean-Pierre PoIrIER, Antoine Laurent de Lavoisier, 1743-1794 (Paris, Editions Pygmalion, 1993); English translation revised and expanded by the author, Lavoisier: Chemist, Biologist, Economist (Philadelphia, University of Pennsylvania Press, 1996). 
Bernadette Bensaude Vincent ${ }^{11}$ have shown, a revolution in chemical method, with the balance of the ledger book becoming the key to judging the success or failure of an experiment. The weight of reactants should equal the weight of products in any chemical operation on magnesia alba. Black would have had no quarrel with this account, but his resistance to the new French nomenclature, and his avoidance of some of Lavoisier's key instruments, makes it clear that his acceptance of Lavoisier's theory was restrained. Others were more enthusiastic in their adoption of the new chemistry. Even where they did not seek to replicate Lavoisier's apparatus, they did seek to design and build apparatus that would perform the same function, but that was cheaper because easier to build, and sometimes easier to use.

In this paper, I shall look at the spread of the new French chemistry in terms of the spread of Lavoisier's instruments. Some of those instruments were traditional and familiar, others were new in their precision, some were relatively new but not invented by Lavoisier and his colleagues, and some were radically new. Lavoisier began his account of the apparatus and manual operations of chemistry with a discussion of balances. Mechanical balances had been central to the chemical laboratory for centuries, and probably for millennia. Medieval alchemists used them, ${ }^{12}$ pharmacists used them, metallurgists used them, and so of course did chemists. But their balances, until the last quarter of the eighteenth century, were relatively crude instruments. Black's balance, ${ }^{13}$ mentioned above and shown in figure 2, was the kind of instrument with which pharmacists and chemists would long have been familiar. Lavoisier's great balance, in contrast, was an instrument built to the most demanding specifications, and evincing that drive for precision which peaked in the second half of the eighteenth century. It was then that superior dividing engines like Jesse Ramsden's, and superior lenses like those made by James Short and also by the Dollonds, typified and made possible the new arsenals of apparatus that natural philosophers and collectors alike coveted. ${ }^{14}$

${ }^{11}$ Bernadette BENSAUdE-VINCENT, Lavoisier: mémoires d'une revolution (Paris: Flammarion, 1993).

12 See, for example, the illustration of an alchemist using a balance in THOMAS NORTON'S Ordinal of Alchemy, British Library MS Add. 10302, f.37v (late fifteenth century), discussed in William R. Newman, "Alchemy, Assaying, and Experiment", in Holmes and Levere (2000), pp.35-54 at p.40.

13 Playfair Collection, Royal Scottish Museum (National Museums of Scotland), 1858.275.3, described in Anderson (1978) pp. 73-75.

${ }^{14}$ M. NORTON WISE, ed., The Values of Precision (Princeton: Princeton University Press, 1994). 


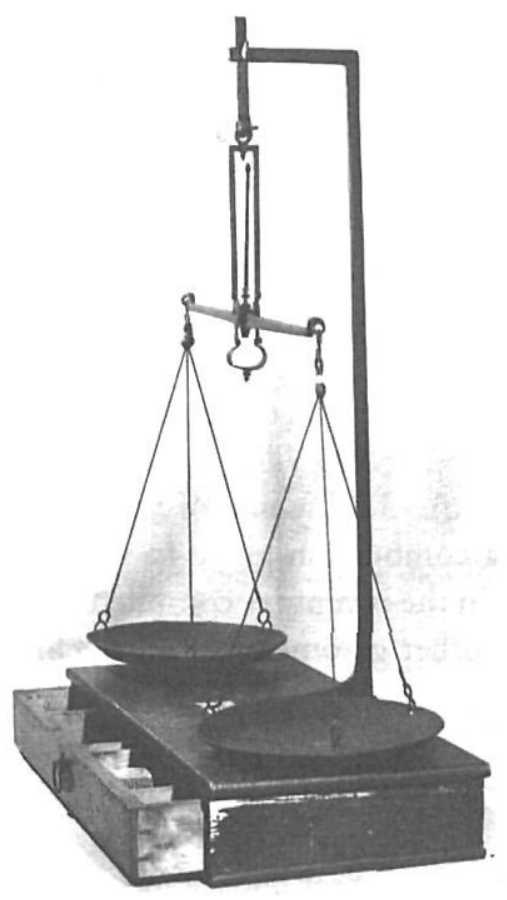

Figure 2: Joseph Black's balance, NMST negative no. 1162, by permission of the Trustees of the National Museums of Scotland.

Most of Lavoisier's apparatus, although unusually well finished, was not new in conception. His laboratory ${ }^{15}$ included a good deal of apparatus that would have seemed familiar to chemists of earlier generations. Among the more than 8000 items recorded after Lavoisier's execution were over 2000 retorts, cucurbits, tanks, stills, and pelicans, most of which would have fitted in well to Boyle's or Duclos's laboratory a century earlier. Until Lavoisier's work, and even for a half-century afterwards, most chemists worked only with glass and ceramic wares, including basins and tea cups, sometimes along with balances, and with the inventive use of accessories such as the rifle barrel used by Joseph Priestley. ${ }^{16}$

15 Marco BerETtA, "Lavoisier's collection of instruments: a checkered history", in Musa Musaei: Studies on Scientific Instruments and Collections in Honour of Mara Miniati, edited by Marco Beretta, Paolo Galluzzi, and Carlo Triarico (Florence: Leo S. Olschki, 2003), pp. 313-334.

${ }^{16}$ R. G. W. Anderson in Dragoni et al. (1994). Priestley's use of a rifle barrel is illustrated in his Experiments and Observations on Different Kinds of Air (London, 1774). 
There were, however, two instruments in Lavoisier's laboratory that were new $^{17}$, and it is in their novelty that Lavoisier saw the practical key to his new chemistry. These instruments were the ice calorimeter and the gasometer. The ice calorimeter (figure 3) was the fruit of collaboration between Lavoisier and Laplace, and Lavoisier used it in the hope of demonstrating conservation of his putative matter of heat. If he had been able to do this, he would have shown that the method of the ledger book, balance and conservation, applied through calorimetry to the matter of heat, just as gravimetric conservation applied to ponderable matter. The great gasometer (figure 4), as its name indicates, was an instrument for measuring gases. The experimental demonstration of the composition of water by the combustion of hydrogen and oxygen required two gasometers, as well as a combustion globe in which the gases combined. One gasometer only is listed in the inventory compiled in 1794, soon after Lavoisier's execution $^{18}$. There is another gasometer in the Technische Museum in Vienna, also made in Paris during Lavoisier's lifetime, which may well be the other one of the pair that he used. ${ }^{19}$

Gas chemistry was central to the chemical revolution, and since this was a revolution based upon the consistent application of experimental quantification ${ }^{20}$, measuring gases took pride of place. Holmes ${ }^{21}$ has shown that Lavoisier's research on gases used simpler and cruder proto-gasometers, so that the grand instruments that he subsequently used in public demonstrations had not in fact been the instruments

17 T. H. LEVERE, "Balance and gasometer in Lavoisier's chemical revolution", Lavoisier et la Révolution Chimique: Actes du Colloque tenu à l'occasion du bicentenaire de lat publication du 'Traité élémtaire de chimie' 1789, edited by M. GoupIL with the collaboration of P. BRET and F. Masson (Palaiseau: ABIX-Ecole Polytechnique, 1992. See also LEvERE, «Lavoisier's Gasometer and others: Research, Control, and Dissemination", Lavoisier Symposium, Deutsches Museum, Munich 2003, to be published by the Museum in the Proceedings of the symposium, edited by Marco Beretta.

${ }^{18}$ Charles, Fortin, and Lenoir, "Inventaire des Instrumens de Physique et de Chymie du Cabinet de Lavoisier cy devt fermier générale et de l'académie des Sciences, Boulevard de La madeleine», le vingt Brumaire de L'an trios, Archives Nationales, Paris, MS F17/1219 Dossier 10, reprinted in Beretta, ed. Beretta, Galluzzi, and Triarico (2003), pp.330-34.

19 Technische Museum Wien, inventory number 11.244, bearing the inscription on the scale, "Fortin place de la Sorbonne à Paris 1790 ". I have not seen the instrument, and am indebted to Dr. Christian Sichau for this information. The inscription may refer only to the scale attached to the instrument.

${ }^{20}$ HOLMES, Antoine Lavoisier (1998).

${ }^{21}$ F. L. Holmes, "The Evolution of Lavoisier's Chemical Apparatus", in Holmes and LEVERE (2000), pp. 137-152. 


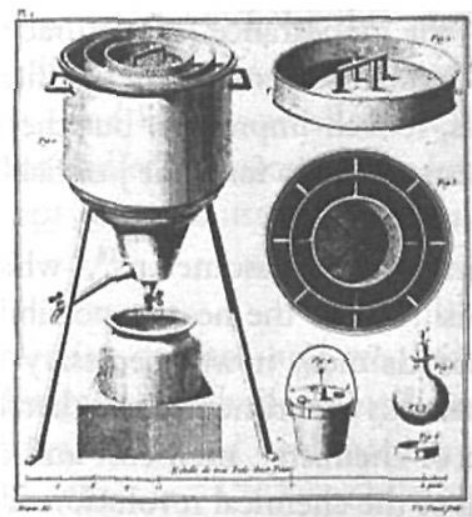

Figure 3: The ice calorimeter of Lavoisier and Laplace, in their «Mémoire sur la chaleur ... 1783 ", plate I.

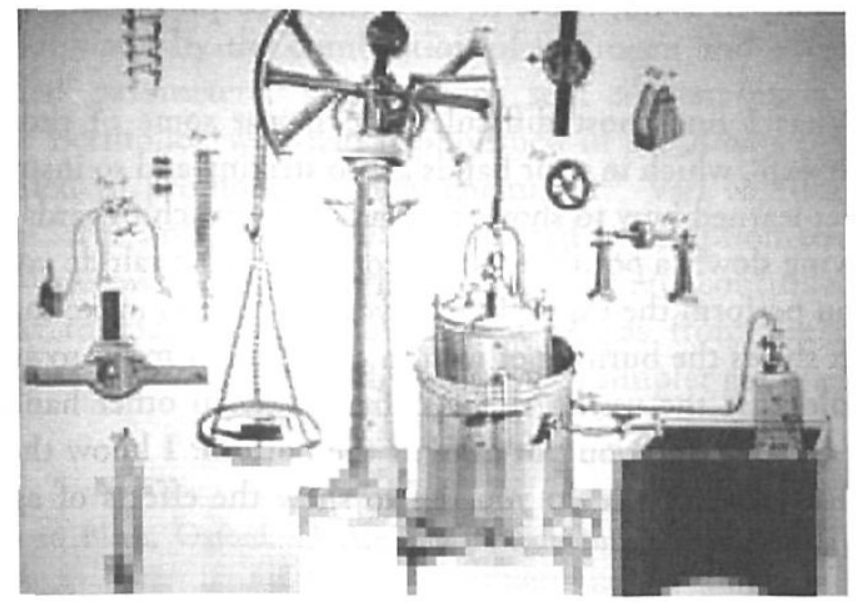

Figure 4: Lavoisier's great gasometer, in Antoine Laurent Lavoisier, Traité élémentaire de chimie, 2 vols. (Paris, 1789). vol. 2, plate VIII.

of research. Nor were Lavoisier's results particularly accurate, whether they were obtained with simple apparatus or with his complex and expensive gasometers. He reported in his Traité that atmospheric air contained 27 parts of oxygen to 73 parts of nitrogen, ${ }^{22}$ a decidedly poor result. But he presented his results as balancing, and 
therefore accurate; and the appearance of accuracy was reinforced by the computational artefact of figures to seven or eight significant places. The figures, like the gasometers themselves, looked impressive, but the results were not, and this aspect of Lavoisier's chemistry came in for some justifiable criticism. ${ }^{23}$

So too did the cost of the gasometers ${ }^{24}$, which, together with their complexity and high finish, led to the near-impossibility of having them built elsewhere. If, as Lavoisier claimed, it was necessary to be equipped with his apparatus in order to repeat his experiments, and thereby to be convinced of the truths of his new system of chemistry, then cost and complexity were going to be obstacles in the spread of the chemical revolution. There are tantalizingly few surviving instruments to show how chemists in the late eighteenth and early nineteenth centuries got around these obstacles. It was hard enough to perform even seemingly simple experiments. Thomas Beddoes, for example, lecturing at Oxford University in 1788 , wrote to his mentor Joseph Black:

What I find most difficult is to repeat some of those apparently simple exps. which in your hands are so striking and so instructive. I have not yet learned how to show the gradual approach towards saturation by throwing slowly a powdered salt into water. What salt do you use? \& how do you perform the exp'? How do you contrive to make that capital expt which shews the burning of iron in dephd air? I mean to attempt it, but am told that the vessel has been frequently in other hands burst with great violence? do you put sand at the bottom? I know the form of the vessel \&c. What salt do you use to shew the effects of agitation upon mixture?25

In 1791 , Beddoes wrote to Black that he had «a very valuable assortment of chemical apparatus -a gazometer very much improved upon $\mathrm{Mr}$ Lavoisier's I\&c/ so that I am able to shew any \& every expt. in his book- It

${ }^{23}$ Jan GoLINSKI, Science as Public Culture: Chemistry and Enlightenment in Britain, 1760 1820 (Cambridge: Cambridge University Press, 1992), p.144.

${ }^{24}$ Charles, Fortin, and Lenoir in BERETTA (2003), p.330.

${ }^{25}$ Dr Thomas Beddoes to Joseph Black, Oxford, 23 February 1788, Edinburgh University Library, MS Gen 873/1II/71, 72. 
has been constructed by a pastry cook in this place, a perfect prodigy in mechanics ..... ${ }^{26}$ The prodigy in question was James Sadler, better known for his work on steam engines, and later as a balloonist. Unfortunately, although we know a good deal about Sadler's later career, we know nothing of Beddoes's improved gasometer, except that it must have been a good deal cheaper than Lavoisier's instrument.

Cheaper meant simpler (or cruder), and we do know about some of the simplified instruments designed and built around Europe in the 1790s. The earliest that I know of was designed and used by the Haarlem chemist, Martinus van Marum, who in 1787 published in Dutch the first comprehensive account of Lavoisier's new chemistry to appear in any language. ${ }^{27}$ Over the ensuing decade, he set about repeating Lavoisier's key experiments, and developed a range of apparatus to perform them more simply and cheaply. In 1791, Van Marum performed the experiment of the composition of water by the combustion of hydrogen and oxygen, using his own simplified gasometers. Van Marum sent a description of his new gasometers to Berthollet, who had it published in the Annales de Chimie, the journal founded to promote the new chemistry. ${ }^{28}$ Van Marum's gasometers consisted of a large bottle or bell jar connected by a siphon to an adjoining taller vessel. Water was fed into the latter vessel at a rate controlled by a system of taps, so as to maintain a constant flow of gas from the bottle to the combustion globe. He went on to design an even simpler gasometer (figure 5),

${ }^{26}$ Beddoes to Black, Oxford, 15 April 1791, Edinburgh University Library, MS Gen $873 / 111 / 200,201$.

${ }^{27}$ Martinus VAN MARUM, "Schets der Leere van M. LAVOISIER, omtrent de zuivere lucht van den dampkring, en de vereeniging van derzelver grondbeginzel met verschillende zelfstandigheden", in Eerste vervolg der proefneemingen, gedaan met Teyler's electrizeer-machine, door Martinus van Marum (Haarlem: Joh. Enschede, 1787), 235-266. This work has been twice reprinted, through the Nederlandsche Chemische Vereeniging, once as "Schets der Leere van M. LAVOISIER" (Haarlem: Joh. Enschedé, 1931), and again in an edition, "SCHETS der LEERE van LaVOISIER door MarTinUS van MARUM ... met een voorrede van A.H.C.A. Wiechmann, een inleiding van H.A.M. Snelders, en annotaties van Jan W. van Spronsen", (Delft: Delftse Universitaire Pers, 1987).

${ }^{28}$ "Lettre de M. van Marum à M. Berthollet, ce L'Académie R. des Sciences, contenant la description d'un Gazomètre, construit d'une manière différente de celui de M.M. Lavoisier \& Meusnier, \& d'un appareil pour faire très exactement l'experience de la composition de l'eau, par combustion continuelle, avec plus de facilité et moins de frais", Annales de Chimie, 12 (1792), 113. 
and it was this simplified apparatus that made its way to collections and museums elsewhere, including the laboratory of the new university in Tartu (Dorpat), ${ }^{29}$ Estonia, and the Hauch collection in Sorø, Denmark. Even though the large bell jars or bottles that feature in these gasometers were simpler than the apparatus used by Lavoisier, they were too difficult for any but skilled - artisans to make. Van Marum's instruments were for some years manufactured by the Netherlands manufacturer J. H. Onderdewyngaart Canzius, who had had factories in Brussels and Delft. Georg Parrot in Tartu complained that local manufacturers were unable to make such pieces, so that when one sent by Canzius in time of war arrived broken, it was a major setback. ${ }^{30}$ Adam Hauch in Sorø developed a gasometer that required much less skill from the glassmaker. It consisted of a large box with panes of flat glass for the sides, and a smaller box inverted over water inside the large box. Pressure on gas contained in the inverted box was maintained by a system of weights and pulleys (figure 6). ${ }^{31}$ The latter innovation had been devised by the instrument maker Dumotiez in Paris, as a simpler and cheaper alternative to Lavoisier's elaborate system of pressure control. ${ }^{32}$ The Fondazione Scienza e Tecnica in Florence has several instruments that incorporate such pulleys. Relatively cheap and versatile gasometers sprung up around Europe, varying in materials (metal, glass, or ceramic) according to the corrosiveness of the gases being handled. There were indeed so many variations on the gasometric theme that Friedrich Parrot, a medical student in Tartu, wrote a prize-winning book-length essay on gasometry, or more strictly on gasometers, in $1811 .^{33}$

29 Erna KoIv, XIX sajandi alguse füüsikariistu Tartu Ülikooli ajaloo muuseumis [Physics Instruments from the Beginning of the $19 t^{h}$ Century in Museum of History of Tartu State University] (Tartu, 1989).

${ }^{30}$ T. H. LEVERE, "Spreading the Chemical Revolution: The Dutch Connection", Bulletin of the Scientific Instrument Society, no. 49 (June 1996), 14-16.

${ }^{31}$ T. H. LEVERE, "The Hauch Cabinet, Chemical Apparatus and the Chemical Revolution", Bulletin of the Scientific Instrument Society No. 60 (March 1999) 11-15.

32 LEVERE in HOLMES and LEVERE (2000), p.125.

33 FRIEDRICH PARROT, Ueber Gasometrie nebst einigen Versuchen über die Vershiebbarkeit der Gase (Dorpat, 1811). 


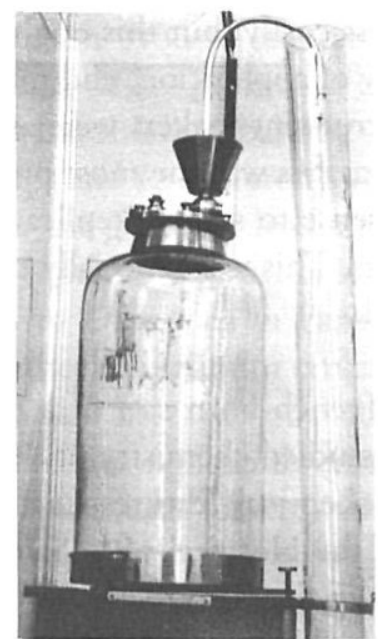

Figure 5: Van Marum's simplified gasometer, Hauch Collection, Sorø, Denmark. Phorograph by the author.

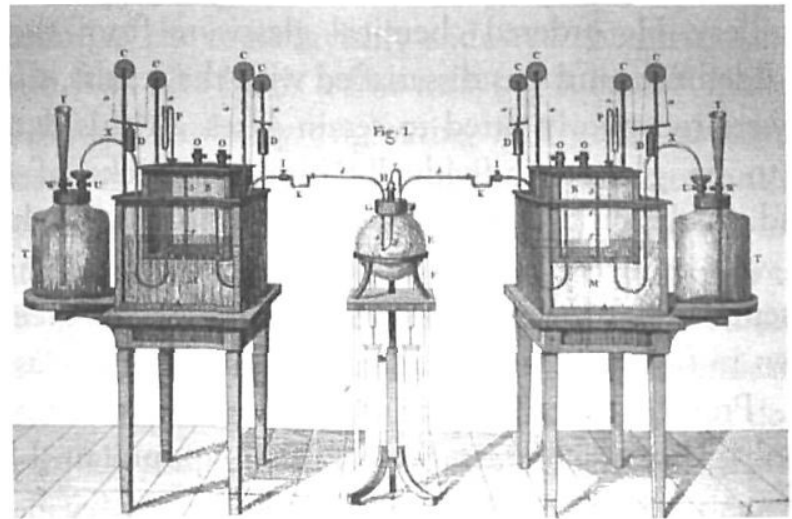

Figure 6: Hauch's gasometers set up for the combustion of hydrogen and oxygen, from A. W. Hauch, «En forbedret Gazometer eller Luftmaaler», Vid. Selsk. Skr. 5 (1793), p.20.

Not everyone, however, was willing to compromise. Lavoisier had been forthright on this matter: "In the present advanced state of chemistry, very expensive and complicated instruments are becoming indispensably necessary for ascertaining the analysis and synthesis of bodies with the requisite precision as to quantity and proportion; it is certainly proper to endeavour to simplify 
these, and to render them less costly; but this ought not to be attempted at the expence of their conveniency of application, and much less of their accuracy.m ${ }^{34}$ So if money and skilled instrument makers were available, and if one assumed that Lavoisier's complex apparatus was the most precise (which was a debatable assumption), then it made sense to seek to replicate his apparatus as a prelude to replicating his experiments. This was especially the case if Lavoisier's support and patronage were involved.

Joseph Louis Proust, ${ }^{35}$ French-born son of a pharmacist, appears to have enjoyed that patronage. He studied chemistry under H. M. Rouelle, brother of the G. M. Rouelle whose chemical lectures Lavoisier attended. In 1776 he became chief pharmacist of the Hospital of la Salpêtrière, and then moved to Vergara (Guipúzcoa) to take up the chair of chemistry. He set about establishing a chemical laboratory, with the help of Rouelle in Paris. He did not stay long in the post, returning to Paris in 1780. In 1785, Proust was invited by the Spanish government to return to Spain. He did so in 1786, teaching first in Madrid, and then in 1788 moved to Segovia, where he became professor of chemistry in the College of Artillery. He ordered chemical glassware from the factory of La Granja de San Ildefonso, and was dissatisfied with the results, since the stoppers for the flasks were too poorly fitted to retain gases. At this date, ground glass stoppers had to be ground individually into the necks of flasks, a timeconsuming and costly procedure. ${ }^{36}$ Proust was indignant when the factory supplied him with crudely finished thick glass vessels, reminiscent of those supplied to Joseph Black by the bottle factory, although less green. The piece of glassware shown in figure 7 shows marked striations in the glass, and a poorly finished neck. Proust turned instead to French instrument makers, who supplied not only glassware, but a variety of other equipment. I have not found

${ }^{34}$ LAVOISIER, Elements of Chemistry, in a New Systematic Order, containing all the modern discoveries, translated by Robert Kerr (Edinburgh: William Creech, 1790), p.319.

${ }^{35}$ The following biographical information about Proust is from Ramon GAGO BOHORQUEZ, "Luis Proust y la Catedra de Química de la Academia de Artilleria de Segovia", published as an introduction to the facsimile reprint (n.p., n.d.) of Luis Proust, Anales del Real Laboratorio de Quimica de Segovia, 2 vols. (Segovia, 1791, 1795). See also Seymour MAUSKOPF, «PROUST, LOUIS JOSEPH", Dictionary of Scientific Biography, ed. C. C. GILlisPIE, vol. 11, pp.166-172, and F. Javier Puerto Sarmiento, "La Huella de Proust: El Laboratorio de Química del Museo de Historia Natural", Asclepio 46 (1994), 197-220.

36 William A. SMEATON, "Platinum and Ground Glass: Some Innovations in Chemical Apparatus by Guyton de Morveau and Others», in HOLMES and LEVERE (2000), pp.211-237. 
an inventory of the apparatus in Proust's laboratory in Segovia. Some of the apparatus surviving in the Casa de la Química is clearly from Proust's era, and of the same workmanship as Lavoisier's apparatus. This is the case with the jars fitted with lacquered brass taps and screw threads (figure 8), for ease of modular assembly and disassembly, or the globe for holding gases, also with a lacquered brass stopcock. Among the signed instruments is a Wedgwood pyrometer, by Pixii, nephew and successor to Dumotiez in Paris. The museum of the Royal Artillery Academy contains a set of platinum crucibles, dishes, wires, cups, etc. The Palacio Real in Madrid also has a set of platinum crucibles, probably of Spanish manufacture from the late eighteenth century. The Spanish empire in South America was the principal source for the metal. If the platinum apparatus in Segovia is from Proust's time there, it is among the earliest known. Proust published a paper on platinum in $1799,{ }^{37}$ at the beginning of the great age of platinum, and in the year in which he moved from Segovia to Madrid, to take on a newly founded chemical laboratory that embraced the previous laboratories in Madrid and Segovia. The laboratory was sumptuously equipped. When Proust requested a supply of platinum, he was given an astonishing 64 kilograms of the metal, in one of the most lavishly endowed chemistry laboratories of its day. ${ }^{38}$ The Palacio Real also holds a fine assaying balance ${ }^{39}$ made by Mégnié le jeune, dated 1788, and probably originating in Proust's laboratory in Segovia. This Mégnié was from the family of Lavoisier's great instrument maker. He had been at the Spanish Royal Observatory from 1786 to around 1790, and returned to Madrid to live there in around 1795 . It is very clear that Proust was a master at getting his way when it came to apparatus and to laboratory facilities. In the course of his inaugural lecture at the Artillery's chemical laboratory in Segovia, he was able to thank not only his patron, the Count de Lacy, but also the late monarch, thanks to whom «su Real Cuerpo de Artillería se vé al momento beneficiado con un Establecimiento, que no tiene igual en toda Europa." ${ }^{40}$

37 Proust, Annales de Chimie 28 (1799), 146, 225.

${ }^{38}$ Mary Elvira WEEKS, Discovery of the Elements, $6^{\text {th }}$ edition (Easton: Journal of Chemical Education, 1956, pp.407-429, especially p.420.

${ }^{39}$ Palacio Real, Madrid, inventory number 10030789.

40 Discurso que en la Abertura del Laboratorio de Chimia del Real Cuerpo de Artilleria, establecido en Segovia, pronunció Don Luis Proust, Professor de Chimia del expresado Real Cuerpo (Segovia: Espinosa, 1792). 


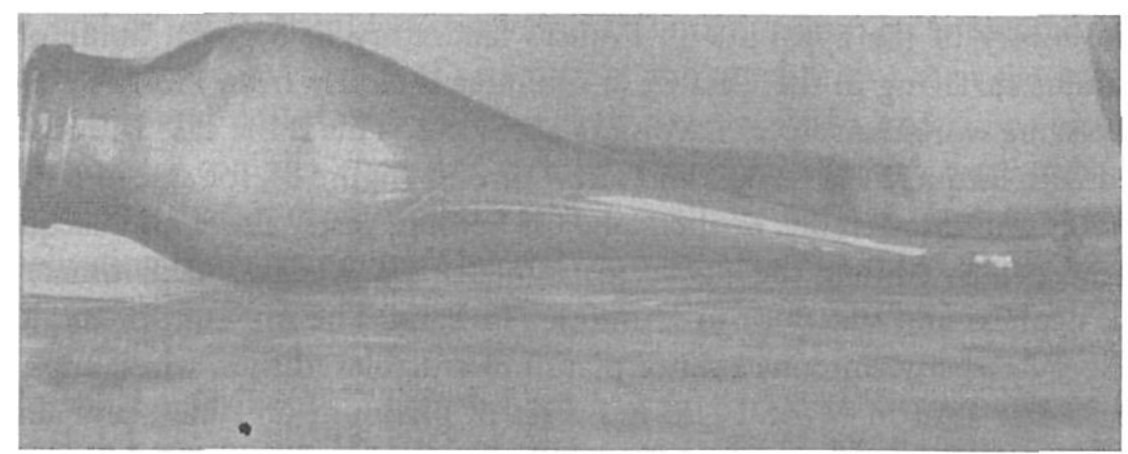

Figure 7: Glassware of Proust's era, showing imperfections, Academia de Artilleria de Segovia, Segovia. Photograph by the author.

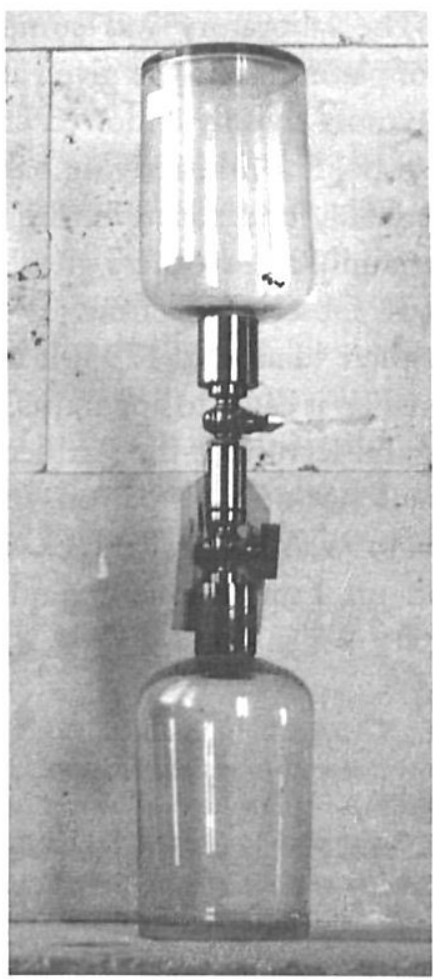

Figure 8: Glassware of Proust's era, with brass taps and threads, following Lavoisier. Academia de Artilleria de Segovia, Segovia. Photograph by the author. 
Proust entitled the two volumes of his researches in Segovia, Anales del Real Laboratorio de Quimica de Segovia, as a deliberate act of homage to the Annales de Chimie founded by Lavoisier and his supporters. Lavoisier had his own fortune and the resources of the Academy of Sciences to fund his laboratory; and, as we have seen in the case of the gasometers, he had argued against making cheaper and simpler apparatus if those economies were achieved by sacrificing convenience and, above all, accuracy. Proust, with the resources of the royal exchequer behind him, could emulate Lavoisier. If Proust was at all justified in his boast that the laboratory in Segovia was without equal in all Europe, then he probably possessed most of Lavoisier's instruments. But it is striking, in looking through his Anales, that his principal concern was with the chemistry of metals, their salts, and their alloys - topics of importance in the manufacture of canons, to pick an example of central importance to the Artillery Corps- but his memoirs scarcely touch on the chemistry of gases that led Fourcroy and others to regard the chemical revolution as the pneumatic revolution. In Segovia there are bottles and globes among other instruments that were used with gases, and that date from Proust's tenure there, but it is clear that pneumatic chemistry was not his research focus. It may, however, have been part of his program of lectures.

In any event, there were clearly different styles involved in adopting the new chemistry, and different approaches to apparatus and experimentation. Black's resistance to new-fangled words and new-fangled apparatus went along with his recognition of the rational power of Lavoisier's chains of experiment. Beddoes, Black's former student, was proud of his ability to demonstrate all the experiments in Lavoisier's book - the Traité elémentaire de chymie of 1789. Beddoes's apparatus had been designed in concert with his instrument maker, Sadler - the role of instrument makers in enlarging the bounds of the possible, and in constraining chemists to work within practical limits, has received too little attention, except perhaps in the development of microscopes, dividing engines, and balances. Holmes showed convincingly that Lavoisier's research was carried out with much cheaper and simpler apparatus than his show pieces, especially the gasometer. The difference between research and demonstration emerges here with particular clarity. Van Marum was not alone in finding the cost and the complexity of Lavoisier's apparatus an impediment both to repeating his experiments, and to demonstrating them publicly to a wider audience. The success of Van Marum's strategy is underlined by the spread of his instruments and by their adoption by Canzius in his catalogues. I do not know if any of Canzius's business records survive, but the survival of his instruments 
in Tartu and Sorø as well as in the Netherlands may be merely the surviving remnant of a larger population; instruments of fragile glass were at risk when shipped around Europe at any time. This was even more the case during the Napoleonic Wars, which were precisely the years of Canzius's greatest production. Van Marum's apparatus also points to another theme - the advantage of simplicity over complexity, which affects not only the difficulties and costs of construction, but also the number of ways in which error can creep into results. That simplicity extends not just to instruments, but to the procedures carried out using them; complex instruments generally required more precautions, and more interpretation of results.

The problems encountered when glass apparatus broke often mean ordering replacements from instrument makers elsewhere - Parrot found that local craftsmen were unable to produce even simple chemical glassware on a scale sufficiently large to be useful in public demonstrations. The kinks in the necks of Black's glassware, and the ill-fitting ground glass stoppers that so angered Proust, also point to the special position of craftsmen capable of producing work of high quality - and the limited numbers of such craftsmen suggests that the supply of fine chemical glasswork must have been severely limited in the years leading up to and immediately following the success of the Chemical Revolution.

Throughout, we are faced with one constant problem: the scarcity of early chemical glassware. It was fragile, and much of it could often only be used once, because until the late eighteenth century, complex apparatus was not made in separable modules. Luting contributed to the problem. And there remains the fact that chemical apparatus in general enjoyed less prestige than the best instruments in several other categories, including telescopes, microscopes, astrolabes, and chronometers. Such physical instruments have been highly valued as the chief objects within cabinets of natural philosophy, and latterly as collectibles. Old chemical glassware is not so glamorous, but where it survives, it reveals much about the practice of chemical science, and the dissemination of those Siamese twins, theory and apparatus. 